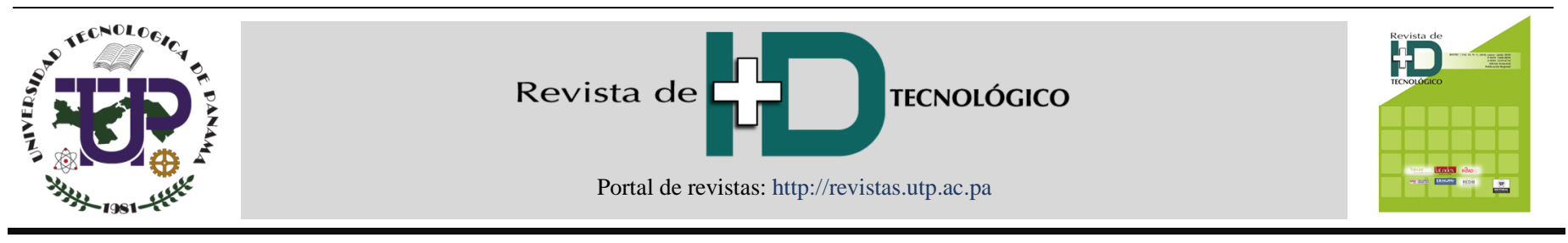

\title{
Analysis and construction of a prosthetic foot
}

\section{Análisis y construcción de un pie protésico}

John Alexander Hernández Martin ${ }^{1 *}$, Luis Alberto Parra Piñeros ${ }^{1}$, César Augusto Pinzón Pinzón ${ }^{1}$, Oscar Heli Bejarano Peña ${ }^{1}$, Jairo Alberto Romero Gutiérrez ${ }^{1}$, Pedro Eladio García Benavides ${ }^{1}$

${ }^{1}$ Centro de Diseño y Metrología, ${ }^{1}$ SENA Regional Distrito Capital, Servicio Nacional de Aprendizaje, Colombia

*Autor de correspondencia: jhonmartin56@gmail.com

\begin{abstract}
The assistive devices for people with disabilities are configured as a set of mechanical, electromechanical, orthotic and prosthetic parts designed to assist in the rehabilitation process of patients who suffered amputation of their lower limbs, whether the injury generates The implementation of a transtibial or transfemoral prosthesis these elements must be performed with proper analysis of preamputation, amputation and post amputation in order to achieve specific objectives for each patient, achieving the best possible treatment. It is important to ensure that in the treatment of lower limb disability by amputation, the best decisions are generated for the patient, with the objective of bringing the patient closer to a normal gait pattern. Considering these characteristics, it will be possible to elaborate a prosthetic element that meets the physical and personal characteristics of the patient such as activity level, age, weight ... etc. Taking into account each of these variables we have decided to analyze in depth a crucial element in the implementation of lower limb prosthesis such as the foot, which we carry from a phase of analysis, design, to implementation in carbon fiber where we currently perform tests with our patients under study.
\end{abstract}

Keywords-Amputation, foot, prosthetic foot, cosmesis.

RESUMEN-Los dispositivos de ayuda para las personas en condición de discapacidad se configuran como un conjunto de piezas mecánicas, electromecánicas, ortésicas y protésicas están diseñados para ayudar en el proceso de rehabilitación de pacientes que sufrieron amputación de sus miembros inferiores, ya sea que la lesión genere la implementación de una prótesis transtibial o transfemoral estos elementos deben realizarse con análisis propios de pre-amputación, amputación y post amputación con el fin de lograr objetivos específicos para cada paciente logrando el mejor tratamiento posible. Es importante garantizar que, en el tratamiento de una discapacidad de miembros inferiores por amputación, se generen las mejores decisiones para el paciente, teniendo como meta acercar al paciente con un patrón normal de la marcha. Considerando dichas características será posible elaborar un elemento protésico que cumpla con las características físicas y personales del paciente como son nivel de actividad, edad peso...etc. Teniendo en cuenta cada una de estas variables hemos decidido analizar a profundidad un elemento crucial en la implementación de una prótesis de miembro inferior como lo es el pie, el cual llevamos desde una fase de análisis, diseño, hasta la implementación en fibra de carbono donde actualmente realizamos pruebas con nuestros pacientes objeto de estudio.

Palabras Clave-Amputación, pie, pie protésico, cosmesis.

\section{Introduction}

Currently, there is a number of prosthetic feet in the market for individuals with transtibial amputation. All of these elements ultimately intend to increase the degree of wellbeing to be offered to the patient; this degree of wellbeing includes elements with a paramount importance, such as size, aesthetics and cost. These factors are rather relevant when implementing a prosthetic component [1]. There are substantial differences as to purpose, materials used in assembly and nominal cost of each of the feet available in the market.

Generally, we can describe the fundamental characteristics as follows: conventional feet refer to feet with zero energy storage potential, such as the Sach type. Another type of foot is energy storing foot, which intends, as pointed out by its name, storing some sort of energy and returning it in the function of walking. Finally, bionic feet, which at some point of walking generate autonomous type movement, which produce movement at some degrees of liberty, based on angular signals or electric potential; this movement is immediately transferred to some of the stages of walking [2][3][4].

Current research determines that results on the different types of feet are still not conclusive, meaning they do not display efficient results along walking cycle and even less over a prolonged period of around 30.000 use cycles. Feet with a more favorable result in walking cycle are the ones that store and somehow return energy 
to the general cycle of walking, since they are not made out of complex elements which depend on programming or patient adaption, but rather their natural founding lies in the use of high-density compounds and geometrical design which mechanically compensate both dorsiflexion and plantarflexion at patient's walk.[5][6][7]. The fundamental purpose of this type of research in the field of orthopedic devices is being able to imitate the biomechanics of human ankle through components which display some sort of relevance when augmenting the levels of wellbeing for the patient, this is what our research seeks, "making a difference" [3].

Making proper analysis, it becomes necessary to have basic functionality, mechanic and esthetic characteristics to be born in mind for appropriate design of a component. Here, we will include the parameters used at the beginning of the design (they correspond to the first stage of the project).

- Patient's body mass: $80 \mathrm{~kg}$

- Shoe size: 34

- Height: $1.70 \mathrm{~m}$

- Activity level: 3

- Stump length: middle third

- State of the stump: Optimum conditions

- Articulation status: Preserved

- Muscular strength: 4

- Maximum foot length: 4

- Dorsiflexion: $20^{\circ}$

- Plantarflexion: $50^{\circ}$

- Manufacturing material: Carbon fiber.

If we put these parameters to good use, it will be possible to fully restore vital elements of the foot, such as weight, cosmesis and durability, besides generating appropriate time to achieve balance between walk and accumulated energy immerse in the component [8][9]; this type of balance is easily verifiable with a walk analysis through a walk behavior laboratory, where the different stages of prosthesis manufacturing are analyzed [10][11] .

Walking pattern is a set of well-articulated movements, which make up a total that can become daily in a person's life. On the other hand, patient's movement can be affected by a great number of anomalies; the most worth noting ones are:

- Diabetes.

- Cerebrovascular accidents.
- Paralysis of lower limbs or other types of paralysis (cerebral).

- Dystrophy of some type.

- Accidents which lead to amputation (Victims of armed conflict)[12, 13][14], among others.

These can lead to the presence of permanent limitations and conditions of disability [15].

An important reference, given that World Health Organization-OMS does not state that $15 \%$ of population suffer some type of disability and indicators in this study lead to believe that this figure is on the rise, and that population numbers with this condition is increasing. For Colombia, the 2005 census from the National Administrative Department of Statistics (Departamento Administrativo Nacional de Estadística en Colombia - DANE) [16], the analysis shows statistics by department on people's disabilities. Most relevant parameters indicate that the departments with the highest figures of disability are Cali (Valle del Cauca), Antioquia and Bogotá. According to this analysis, the official figure for this year suggests that in Colombia there are 2'624.898 disabled people. Off the record, by 2015 the WHO claimed the same indicator to be $3^{\prime} 051.217$. For specifically physical disabilities, the figure corresponds to $29,3 \%$ of the population, according to the same statistics [17][18].

This analysis generates the necessity of designing and implementing our own prototype, according to geographic, labor and socioeconomic considerations; which complies with morphological parameters of the patients who have suffered amputation due to the armed conflict, disabled soldiers, whose average weight ranges $80 \mathrm{Kg}$. These factors, along with proper alignment [19], and further walking analysis [20][21], can provide a prototype capable of resisting high impact and functionally accommodating to the design parameters required [22].

\section{General analysis of prosthesis}

The analysis pf prosthesis begins with the parameters taken into account when designing the prosthetic component, which will not be discussed, as they have been thoroughly treated in previous papers [23].

The elaboration of the foot in carbon fiber is determined starting from the design and specifications, based on anthropometric and biomechanical measurements, specific to the patients object of study. 
First, sketches are modeled by specialized staff of the school of orthopedic technology of the Centro de Diseño y Metrología-SENA Center for Design and Metrology-SENA.
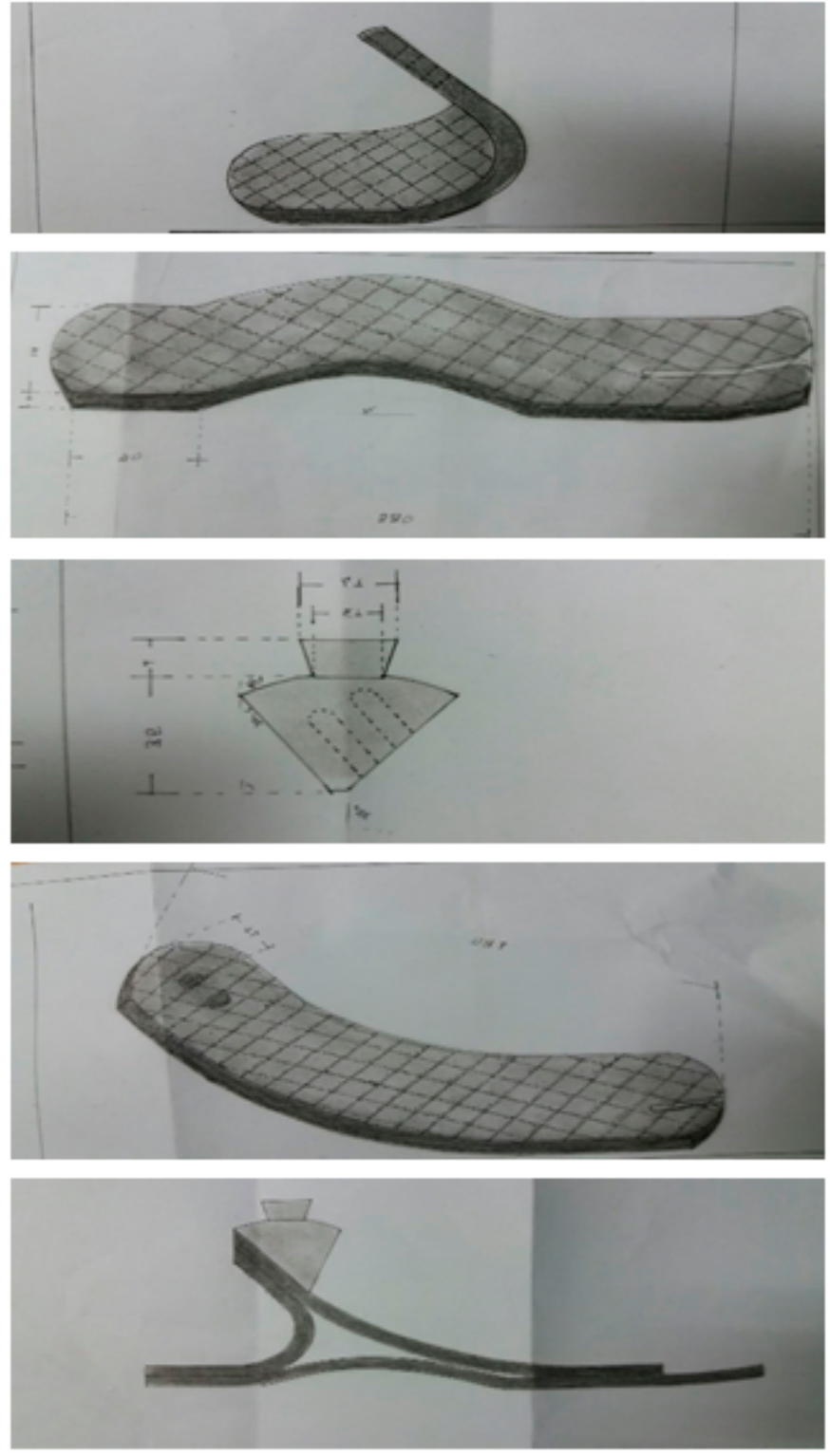

Figure 1.a) Ankle b) Sole c) Adapter d) Instep e) General.

Next, the design is elaborated using micro porous sheets.

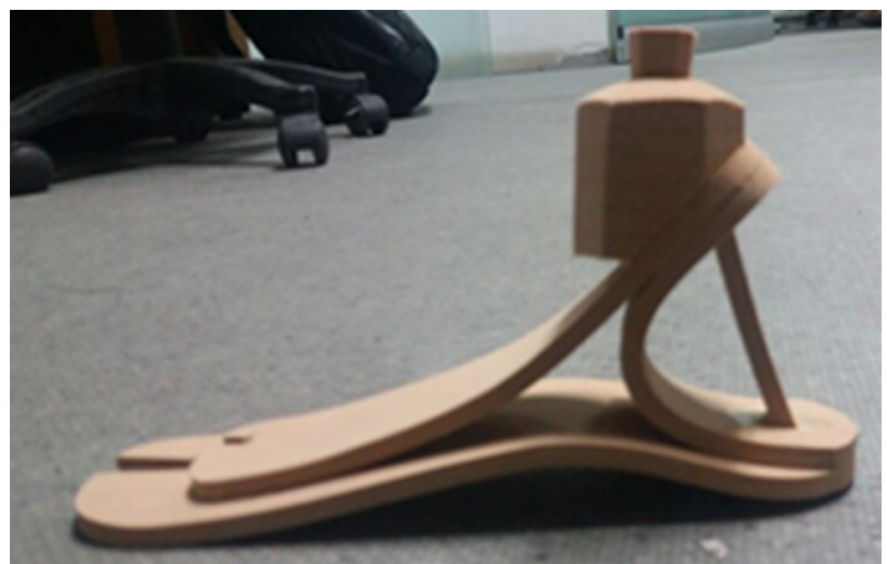

Figure 2.General assembly in micro porous sheets.

\section{Full articulation assembly}

In the general prosthesis assembly, the first step is making molds in plaster to make each of the components which compose the device, complying with required dimension (activity, weight, length, width, thickness, degrees, height).

Afterwards, the first tests were made with molds, using 100 grs of acrylic resin; 6 strips of carbon fiber were cut bidirectionally at $90^{\circ}$; the six layers of fiber were put in the mold, and the resin was poured inside. The mold was pressed until hardened for four (4) hours; then it was extracted from the mold and burr was removed from the pieces obtained. Uniformity and resistance of the piece were checked (Stencil, heel, instep, adapter) in anticipation for assembly. This process was repeated with each of the pieces forming the model.

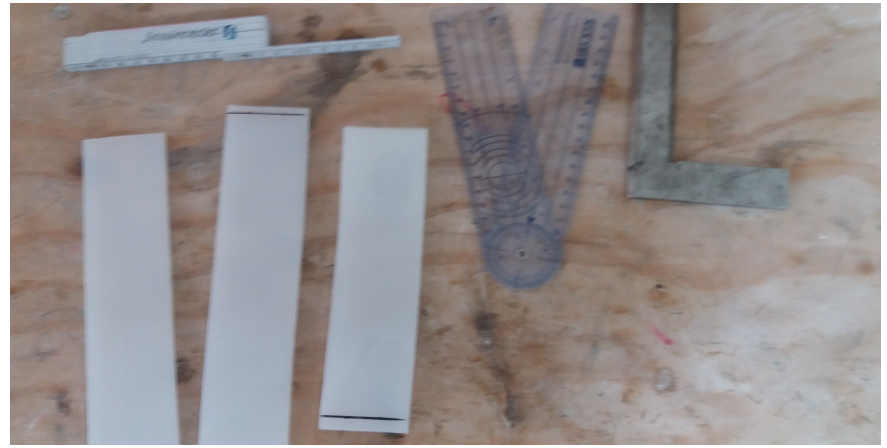



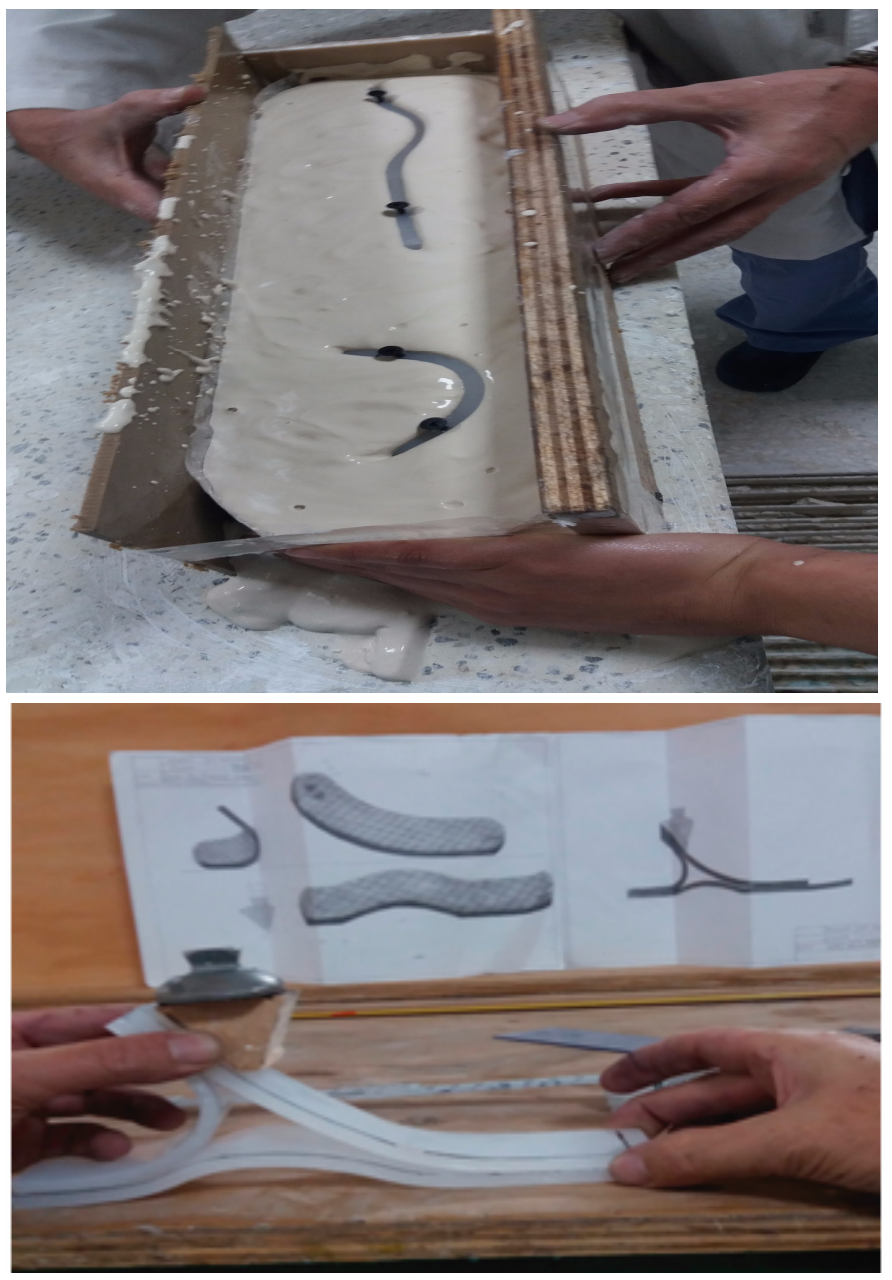

Figure 3. a) Stencils b) Mold c) Assembly.

Once all the pieces have been obtained, and their quality has been checked, they are assembled, paying special attention to proper alignment and fitting.

Proper adaptation is checked when assembling the components, thus determining the alignment recommended and optimal for socket and prosthetic foot respectively.

\subsection{Materials and method}

Given that the article is shown as a set of experiences for the manufacture of an element it is necessary to specify the methodologies required to make the different prototypes, the methodologies used were the casting molding where prototype was obtained in polypropylene in thermoplastic, after that a molding was made for carbon fiber construction with 6 layers of bidirectional carbon fiber placed at $90^{\circ}$, the adapter was made with a duralumin block machined in a four axis lathe, the description of the elements is as follows:

-Polypropylene.

- Duralumin.

- Carbon fiber in bidirectional mantle.

- Rivets.

The final result of our manufacture is the following:

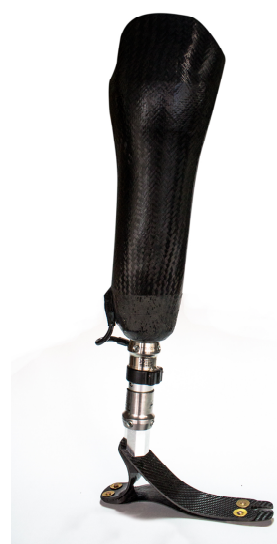

Figure 4. Final Assembly.

\section{Model analysis and results by finite elements}

To begin the analysis, the prosthesis was defined in a model format $*$ igs for proper visualization and software adjustment during the use of the structural analysis module.

In the first step, the prosthesis was visualized fully and all components were verified.

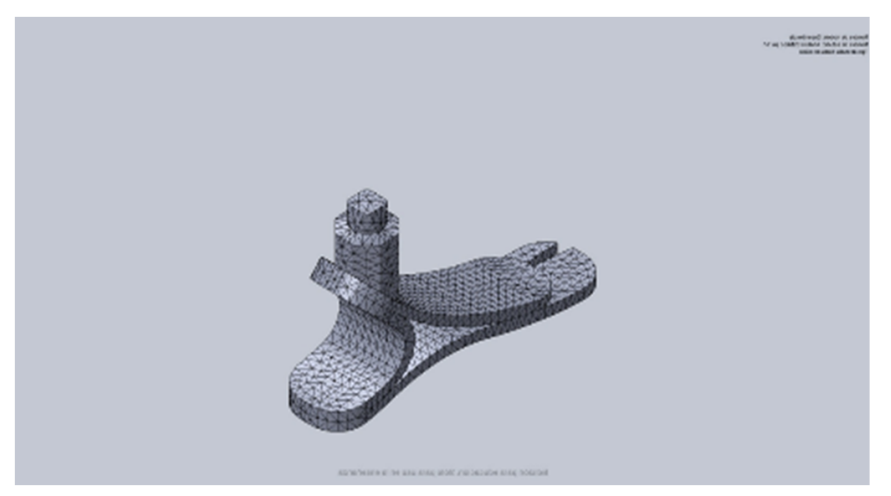




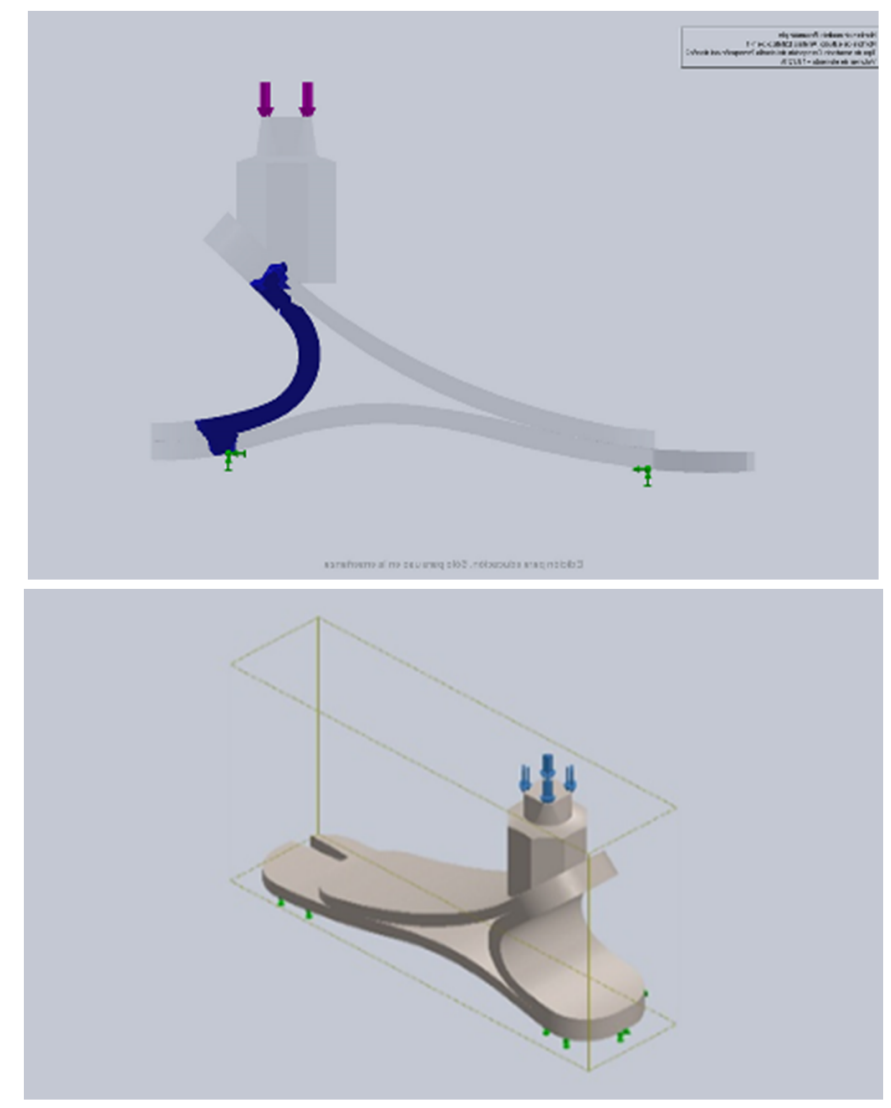

Figure 5. a) Tetragonal mesh b) Forces implementation c) Forces applied on critical elements.

When mesh visualization was finished, a single load vector was applied, corresponding to $100 \mathrm{Kg}$, located in the zone where the previously analyzed socket or adapter will be placed. The load is studied as follows (figure 5) and it is verified to make sure it is not tilted.

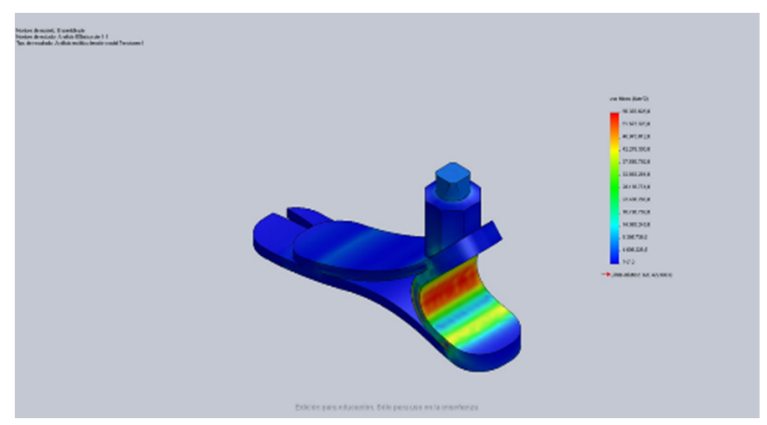

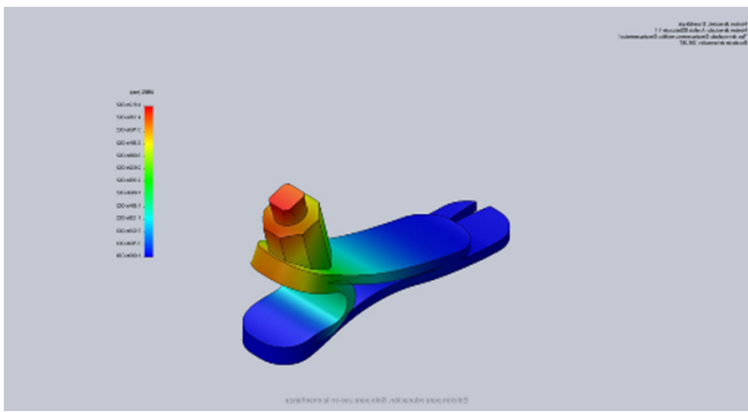

Figure 6.a) Von Misses tension force $100 \mathrm{Kg}$.

b) Implementation of forces focused on the adapter.

Table 1. Results of the static analysis for tension

\begin{tabular}{|c|c|c|c|}
\hline Name & Type & Min. & Max. \\
\hline Tension & VON: & 717.23 & $5.63708 \mathrm{e}+007$ \\
& von & $\mathrm{N} / \mathrm{m}^{\wedge} 2$ & $\mathrm{~N} / \mathrm{m}^{\wedge} 2$ \\
& Misses & & \\
& tension & Node: & Node: 12505 \\
& & 10111 & \\
\hline \multicolumn{3}{|c|}{ Static analysis feet- Tensions } \\
\hline \multicolumn{3}{|c}{} \\
\hline
\end{tabular}

Table 2. Results of static analysis for displacement

\begin{tabular}{|c|c|c|c|}
\hline Name & Type & Min. & Max. \\
\hline Displacements 1 & URES: Resulting & $0 \mathrm{~mm}$ & 0.045 \\
& displacement & & 1218 \\
& & Node: & $\mathrm{mm}$ \\
& & 6919 & \\
& & & Node: \\
& & 699 \\
\hline \multicolumn{3}{|c|}{ Static analysis foot- displacements } \\
\hline
\end{tabular}

Table 3. Results static analysis for deformations

\begin{tabular}{|l|l|l|l|}
\hline Name & Type & Min. & Max. \\
\hline Unitary & ESTRN: & $3.82251 \mathrm{e}$ & 0.0001715 \\
& Equivalent & -009 & 92 \\
& Unitary & & \\
& Deformation & Element: & Element: \\
& & 5949 & 7141 \\
\hline
\end{tabular}


Mostly, foot components display aggressive curve radiuses and fatigue failure possibility, due to the permanent load cycle it will endure. Therefore, breaking points, displacements and deformations, were revised, as seen in tables 1,2 and 3. In latter manufacturing, these issues will be corrected.

\subsection{Security factor}

Since the safety factor is configured as the relationship between the maximum stress and the permissible stress of the material. And performing the respective calculation for the model gives us a value of $8 \%$, assuming then that the value is eight points above. Exceeding widely the fracture values of the material.

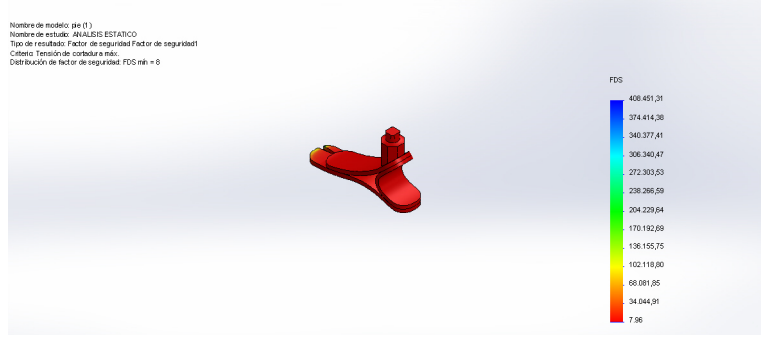

Figure 7. Security Factor 8\%.

\section{Conclusions}

- In the first test with molds, we were able to prove that it is not functional, due to the limited space of the piece for proper accommodation of carbon fibers.

- Mostly, fot components display aggressive curve radiuses and fatigue failure possibility, due to the permanent load cycle it will endure.

- For the case of the ankle, it is necessary to comply with active flection and extension movements in the load and balance phase, in order to resemble static and dynamic movements (cinematic) of physiological walk.

- Foot must respond to mechanical functions of ankle component and assume functions proper to said component.

- The value of the safety factor is $8 \%$, which allows us to have peace of mind in the use of the materials and the use that has been given to this piece, for greater safety we are making the test tubes for analysis and the respective analysis of march for the proper use of the prosthesis.

\section{Referencies}

[1] C. Curtze, A. L. Hof, H. G. van Keeken, J. P. Halbertsma, K. Postema, and B. Otten, "Comparative roll-over analysis of prosthetic feet," Journal of biomechanics, vol. 42, pp. 17461753, 2009.

[2] J. D. Ventura, G. K. Klute, and R. R. Neptune, "The effect of prosthetic ankle energy storage and return properties on muscle activity in below-knee amputee walking," Gait \& posture, vol. 33, pp. 220-226, 2011.

[3] H. Masum, S. Bhaumik, and R. Ray, "Conceptual Design of a Powered Ankle-foot Prosthesis for Walking with Inversion and Eversion," Procedia Technology, vol. 14, pp. 228-235, 2014.

[4] A. Mai and S. Commuri, "Intelligent control of a prosthetic ankle joint using gait recognition," Control Engineering Practice, vol. 49, pp. 1-13, 2016.

[5] D. Heitzmann, J. Block, M. Alimusaj, and S. Wolf, "Evaluation of a novel prosthetic foot while walking on level grotimesund, ascending and descending a ramp," Gait \& Posture, vol. 42, pp. S94-S95, 2015.

[6] A. D. Segal, K. E. Zelik, G. K. Klute, D. C. Morgenroth, M. E. Hahn, M. S. Orendurff, et al., "The effects of a controlled energy storage and return prototype prosthetic foot on transtibial amputee ambulation," Human movement science, vol. 31, pp. 918-931, 2012.

[7] B. W. Townsend and B. K. Claudino, "Prosthetic foot with tunable performance," ed: Google Patents, 2003.

[8] K. Z. Takahashi and S. J. Stanhope, "Mechanical energy profiles of the combined ankle-foot system in normal gait: insights for prosthetic designs," Gait \& posture, vol. 38, pp. 818-823, 2013.

[9] M. Van der Linden, S. Solomonidis, W. Spence, N. Li, and J. Paul, "A methodology for studying the effects of various types of prosthetic feet on the biomechanics of trans-femoral amputee gait," Journal of biomechanics, vol. 32, pp. 877-889, 1999.

[10] B. A. Ebrahimi, S. R. Goldberg, and S. J. Stanhope, "Changes in relative work of the lower extremity joints and distal foot with walking speed," Journal of Biomechanics, 2017.

[11] D. Rusaw and N. Ramstrand, "Sagittal plane position of the functional joint centre of prosthetic foot/ankle mechanisms," Clinical Biomechanics, vol. 25, pp. 713-720, 2010.

[12] R. Diaper, E. Wong, and S. A. Metcalfe, "The implications of biologic therapy for elective foot and ankle surgery in patients with rheumatoid arthritis," The Foot, 2017.

[13] P. Seng, F. Theron, E. Honnorat, D. Prost, P.-E. Fournier, and A. Stein, "Raoultella ornithinolytica: An unusual pathogen for prosthetic joint infection," IDCases, vol. 5, pp. 46-48, 2016.

[14] D. C. Morgenroth, A. D. Segal, K. E. Zelik, J. M. Czerniecki, G. K. Klute, P. G. Adamczyk, et al., "The effect of prosthetic foot push-off on mechanical loading associated with knee osteoarthritis in lower extremity amputees," Gait \& posture, vol. 34, pp. 502-507, 2011.

[15] S. Portnoy, A. Kristal, A. Gefen, and I. Siev-Ner, "Outdoor dynamic subject-specific evaluation of internal stresses in the 
residual limb: hydraulic energy-stored prosthetic foot compared to conventional energy-stored prosthetic feet," Gait \& posture, vol. 35, pp. 121-125, 2012.

[16] C. G. de la Nación, "Primer informe de seguimiento y monitoreo de los entes de control a la ley 1448 de 2011 de víctimas y resttución de tierras," ed: Bogotá, 2012.

[17] A. a. Victimas, "Direccion Contra Minas, Ministerio De Postconflicto Derechos Humanos Y Seguridad," 2016.

[18] C. I. D. L. C. ROJA, "Minas terrestres: legado de la guerra," 2016.

[19] S. Litzenberger, A. Sabo, and F. K. Fuss, "Effect of different mounting angles of prosthetic feet dedicated to sprinting on reaction forces," Procedia Engineering, vol. 147, pp. 490-495, 2016.

[20] B. Altenburg, M. Bellmann, T. Schmalz, J. Sottong, and S. Blumentritt, "Biomechanical investigation of currently available microprocessor controlled prosthetic feet," Gait \& Posture, p. S94, 2015.

[21] A. Eisner, J. Rosati, and R. Wiener, "Experimental and theoretical investigation of particle-laden airflow under a prosthetic mechanical foot in motion," Building and Environment, vol. 45, pp. 878-886, 2010.

[22] P. Taboga and A. M. Grabowski, "Axial and torsional stiffness of pediatric prosthetic feet," Clinical Biomechanics, 2017.

[23] J. H. Martin., L. A. P. Piñeros., and G. A. M. Mendieta, "Design and implementation of transtibial prosthesis", 2016. 